\title{
LETTER
}

\section{Contribution of activated platelets to plasma IL-27 levels}

\author{
Hind Hamzeh-Cognasse', Pauline Damien', Kim Anh Nguyen', Fabrice Zeni',2, Bruno Pozzetto, ${ }^{1,3}$, Fabrice Cognasse ${ }^{1,4}$ \\ and Olivier Garraud ${ }^{1,4, *}$
}

See related research by Wong et al., http://ccforum.com/content/16/5/R213

In a recent issue of Critical Care, Wong and colleagues [1] demonstrated that the serum concentration of IL-27 in critically ill children was a predictor of infection. Our study aims at determining whether platelet activation contributes to the elevated plasma IL-27 concentration. Here we demonstrate that activation of platelets with thrombin receptor activating peptide (TRAP) significantly increased IL-27 levels in supernatants (Figure 1a). Moreover, B cells incubated in vitro with supernatants from activated platelets upregulated membrane expression of CD86, which was restored to baseline when B cells were pre-incubated with a gp130 blocking antibody (Figure 1b). Our data strongly suggest that platelet activation contributes, along with classical sources [2], to elevated plasma levels of IL-27. Recent advances place platelets as an important link between innate and adaptive immunity [3]. Indeed, platelets modulate their inflammatory response after sensing the presence of an infectious agent [4]. Therefore, platelet activation could contribute to increased plasma concentrations of IL-27 along with cytokines such as soluble CD40L [5], and thus may contribute towards immune dysregulation in patients with sepsis.

\section{Abbreviations}

IL, interleukin; TRAP, thrombin receptor activating peptide.

\section{Competing interests}

The authors declare that they have no competing interests.

\section{Acknowledgements}

The authors thank MA Eyraud and CA Arthaud for technical assistance. This work was supported by the EFS (grant APR2010-No10) the ANR (grant ANR-12JSV1), the ART, and the 'Les Amis de Rémi' Association; France. In accordance with French regulations, platelets were obtained from regular blood donors who signed a form indicating that they do not preclude the use of their sample for medical research.

\section{Author details}

'Université de Lyon, F-42023, GIMAP, EA3064, Saint Etienne, France. ${ }^{2 S}$ ervice de reanimation medicale, $\mathrm{CHU}$ de Saint-Etienne 42270, France. ${ }^{3}$ Laboratoire de bacteriologie-virologie, CHU de Saint-Etienne 42270, France. ${ }^{4}$ EFS AuvergneLoire and GIMAP-EA 3064, Université de Saint-Etienne, Faculté de Médecine, 15 rue Ambroise Paré, 42023 Saint-Etienne cedex 2, France.

Published: 5 February 2013

\section{References}

1. Wong HR, Cvijanovich NZ, Hall M, Allen GL, Thomas NJ, Freishtat RJ, Anas N, Meyer K, Checchia PA, Lin R, Bigham MT, Sen A, Nowak J, Quasney M, Henricksen JW, Chopra A, Banschbach S, Beckman E, Harmon K, Lahni P, Shanley TP: Interleukin-27 is a novel candidate diagnostic biomarker for bacterial infection in critically ill children. Crit Care 2012, 16:R213.

2. Wojno ED, Hunter CA: New directions in the basic and translational biology of interleukin-27. Trends Immunol 2012, 33:91-97.

3. Semple JW, Italiano JE Jr, Freedman J: Platelets and the immune continuum. Nat Rev Immunol 2011, 11:264-274.

4. Berthet J, Damien P, Hamzeh-Cognasse H, Pozzetto B, Garraud O, Cognasse F: Toll-like receptor 4 signal transduction in platelets: novel pathways. $\mathrm{Br} \mathrm{J}$ Haematol 2010, 151:89-92.

5. Lorente L, Martín MM, Varo N, Borreguero-León JM, Solé-Violán J, Blanquer J, Labarta L, Díaz C, Jiménez A, Pastor E, Belmonte F, Orbe J, Rodríguez JA, Gómez-Melini E, Ferrer-Agüero JM, Ferreres J, Llimiñana MC, Páramo JA: Association between serum soluble CD40 ligand levels and mortality in patients with severe sepsis. Crit Care 2011, 15:R97.

\section{doi:10.1186/cc11925}

Cite this article as: Hamzeh-Cognasse $\mathrm{H}$, et al:: Contribution of activated platelets to plasma IL-27 levels. Critical Care 2013, 17:411.
*Correspondence:. E-mail address: olivier.garraud@efs.sante.fr

“EFS Auvergne-Loire and GIMAP-EA 3064, Université de Saint-Etienne, Faculté de

Médecine, 15 rue Ambroise Paré, 42023 Saint-Etienne cedex 2, France

Full list of author information is available at the end of the article 
(a)

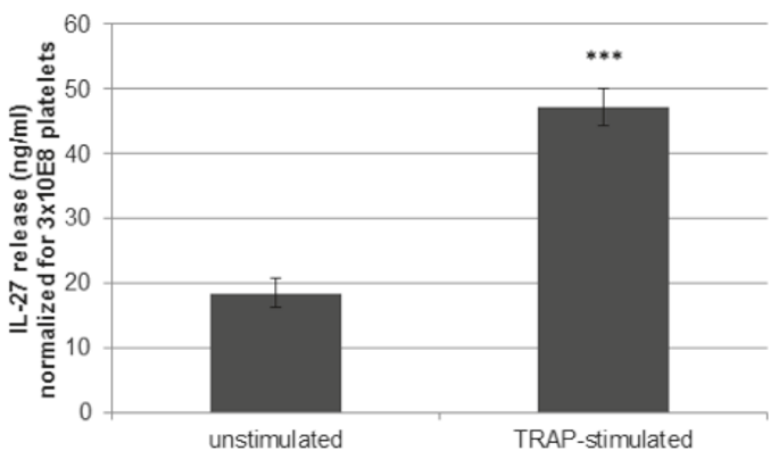

(b)

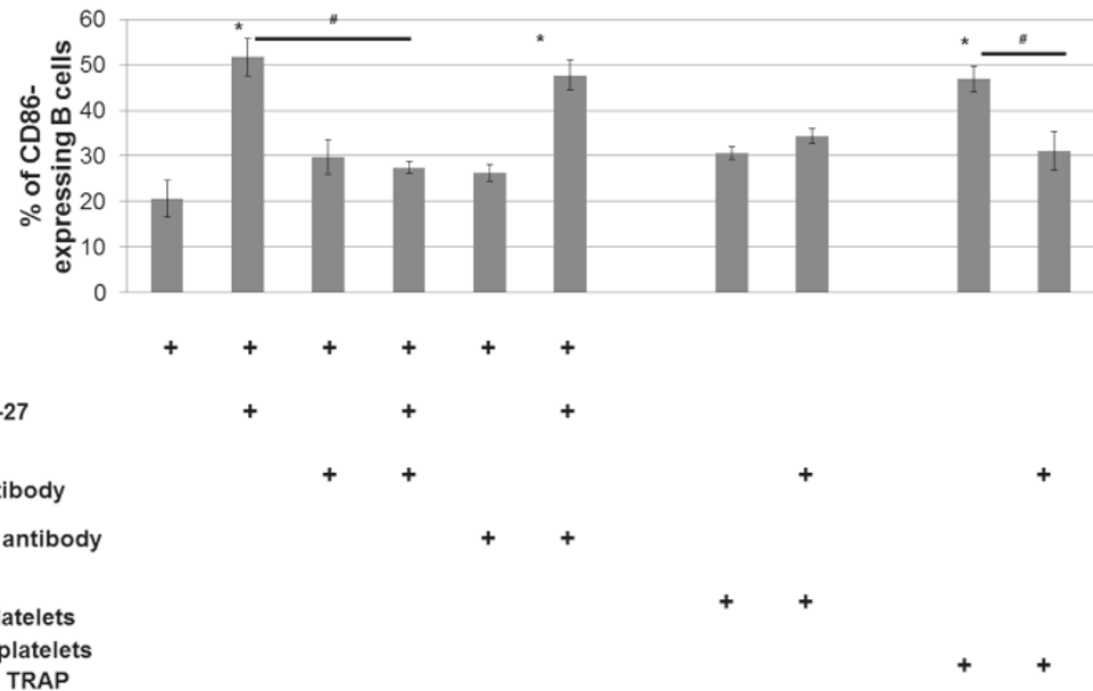

Figure 1. Activated platelets release abundant and functional IL-27. (A) Platelets from apheresis platelet concentrates $(n=11)$ were stimulated with TRAP-SFFLRN peptide ( 50 mg/ml, 30 minutes; Sigma-Aldrich, Saint-Quentin Fallavier, France); negative controls were not stimulated. IL-27 concentration in platelet supernatants was determined using a commercial enzyme-linked immunosorbent assay kit (RnD Systems Europe, Lille, France). Thrombin receptor activating peptide (TRAP) stimulation significantly increased IL-27 release from $18.42 \pm 2.28 \mathrm{ng} / \mathrm{ml}$ to $47.17 \pm 2.99 \mathrm{ng} /$ $\mathrm{ml}\left({ }^{* * *} P<0.0005, t\right.$-test). (B) Then, the influence of IL-27-rich platelet supernatants on the expression of the activation marker CD86 was assessed in vitro on five independent highly purified blood B lymphocyte sets by means of flow cytometry, in duplicate for each condition. As a control, each set of B cells was incubated in minimal medium for $48 \mathrm{~h}$ with recombinant IL-27 (10 ng/ml; RnD Systems). We found that, in contrast to supernatants of non-activated platelets, supernatants of activated platelets provoke a significant increase in CD86 expression on B cells from 21 to $47 \%\left({ }^{*} P<0.05\right.$, $t$-test). CD86 expression was restored to baseline when B cells were pre-incubated with an antibody blocking the gp130 subunit of the IL-27 receptor $\left(0.5 \mathrm{\mu g} / \mathrm{ml}\right.$; clone 28126, RnD Systems; ${ }^{\sharp} P<0.05, t$-test). Results are presented as mean values \pm standard deviations. 